\title{
Economic Growth through Educational Participation and Clean Water: The Case from 500 Districts and Cities in Indonesia
}

\author{
Sidik Budiono ${ }^{1}$ and John Tampil Purba ${ }^{2}$ \\ \{sidik.budiono@uph.edu',john.purba@uph.edu ${ }^{2}$ \} \\ Faculty of Business and Economics, Universitas Pelita Harapan \\ Lippo Karawaci Tangerang, Indonesia ${ }^{1,2}$
}

\begin{abstract}
The progress development of a country on this planet can be seen from its economic growth whether it continues to increase or not. The Republic of Indonesia has several regional characteristics that have it in achieving economic growth. This study aims to see how the influence of household access to the availability of clean water and the level of participation of elementary and junior high schools on economic growth. This study uses secondary cross-section data from 500 districts and cities from all over Indonesia. The analytical method used is multiple regressions using Ordinary Least Square (OLS). The calculation results show that household access to clean water and junior high school level participation influence a significant value on economic growth in the areas surveyed. Therefore, research can be used for government policies that manage education at the junior secondary level and which manage clean water in the country so that households can have access to obtain better economic benefits in the coming days.
\end{abstract}

Keywords: water, enrolment of schooling, Gross Domestic Regional Product

\section{Introduction}

GDRP growth is one indicator of the performance of the nation's economy, including Indonesia. Social, cultural, economic and political factors contribute to the country's economic achievements. For the purpose of simplifying the problem, various economic theories that economic growth is influenced by key reasons related to bodily investment and human capital [1] [2]. The development of human capital can be marked by the fulfillment of living standards, health, and the level of education participation. While the development of physical capital is characterized by the presence of inputs including assets, machinery, equipment, and so on. Therefore, physical capital can also be represented by the basic needs of the community, namely clean water. So the two types of basic needs are crucial that together affect the country's economic growth [3].

Meanwhile, the level of ability of human life can be improved by increasing education through school participation at every grade of education and capabilities training. So, the quality of labor is an endogenous factor that can determine the process of aggregate economic growth. The view of ideas / innovation in technology and lean towards to make the way of production towards capital productivity intensive. Global competition of products has encouraged the creativity of ideas and innovations in all countries. In line to the argue of Gylfason and Zoega that training programs are important to maintain and recycle continuously become the role of human capital as well as for the better production process [1].

By improving the quality of human life through good education, health, and poverty eradication programs is seen as an investment for the human resources. Health and Education are non-intangible and invisible assets, which play in the long run become an important role in forming skilled human capital. Human characteristics are active resources in development, therefore they are as important as physical capital which must always be improved and developed continuously through education, health and living standards. So one measure / indicator of qualitative human capital is the length of time an individual attends school (school participation) [4].

The most important and must-have element for humans is clean water. Therefore, the clean water become the basic necessity for humans for various uses. Access by households, agriculture and industry to clean water needs is 
the most basic right. All mankind have an inherent right to have access to clean water in level of quantities and of a quality necessary to meet their basic needs. Therefore, state law must also protect the most basic rights [5] [6]. So access to clean water needs to be regulated by the state through appropriate program plans and management of supply and distribution. Access to the fresh and water can improve the economic events more effectual and supportive. The readiness and access of adequate clean water also changes the pattern of individual views in their lives and opportunities. In the end, the availability of clean water provides multiplier advantages in socio-economic life [7]. figure.

Indonesia's GDP growth based on prices prevailing during the period 2010 to 2017 can be seen in the this

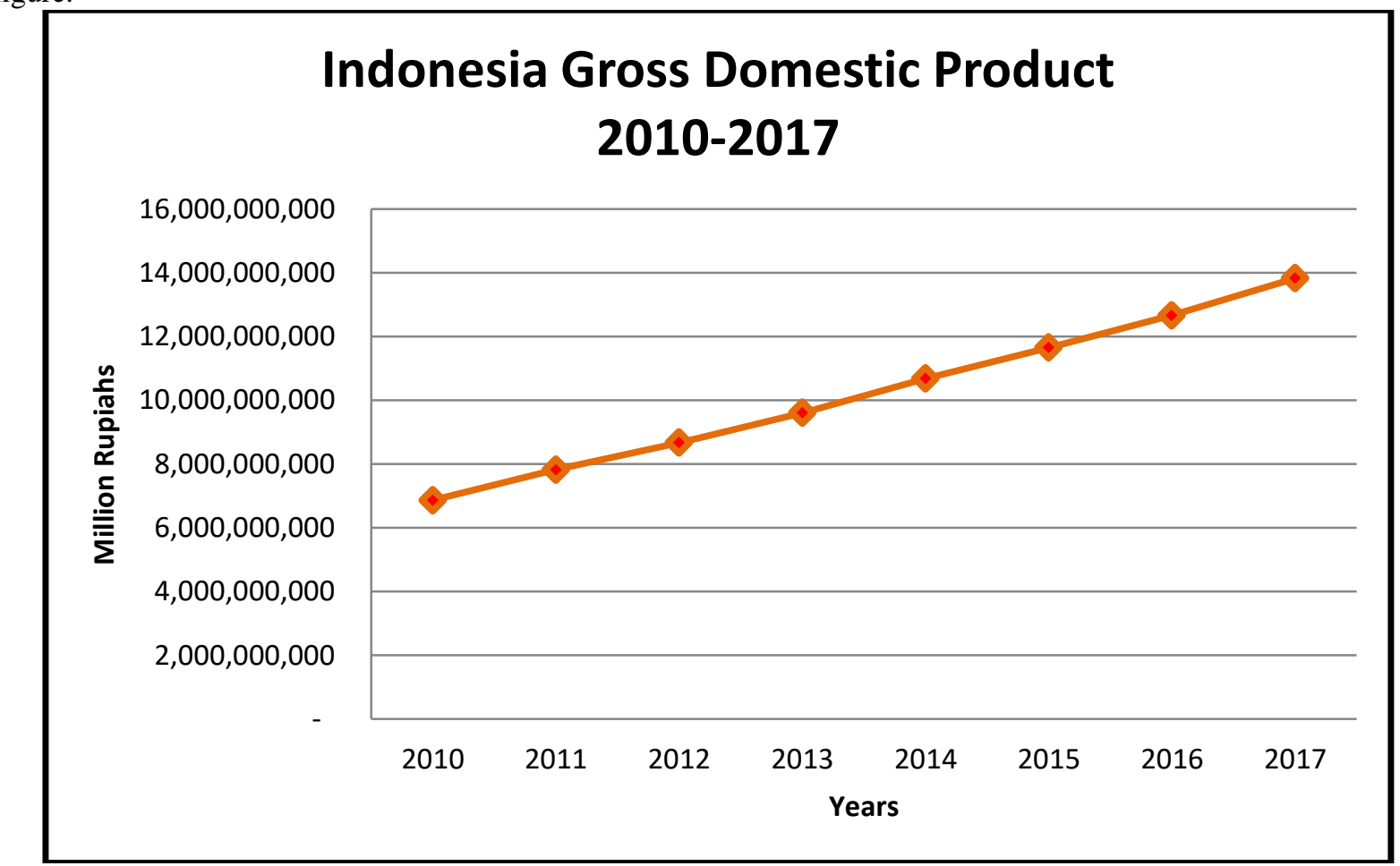

Fig. 1. Indonesia's GDP Growth within 2010-2017.

Indonesia's GDP growth always increases every year, this reveals that the Indonesian economy is stable in the face of shocks from the internal and external of the country. Within 8 years, the volume of the Indonesian economy nearly doubled even though this calculation was triggered by inflation factors. As known with this situation has led the economy of this country to become one of the prime economies of measure in this region. The unique limitation is because the diversity of the population and economic activities that are spread over such a wide area do not have a negative impact on the Indonesian economy. With the case of amazing development of the Indonesian economy that it is interesting to be discuss in this study. Therefore, in this study, we want to know how far the impact of humanoid capital through enlightening education participation and physical capital through the existence of household access to clean water on economic development.

\section{Literature Review}

The unique limitation is due to the diversity in one as Pancasila; the people and economic events that are feast over such a wide area on the country wide do not have a negative influence on the national economy. Such an unusual progress of the economy that it is interesting one to study in this paper. Therefore, with this research wants to know how far the influence of human capital through educational participation and the presence of household access to clean water on economic growth. Management of policies on science and technology requires specific approaches and strategies in an ever-changing environment. Science and technology are the initial foundation that can produce ideas which then become useful new innovations for development of the country [8] [9]. 
The accumulation of the human capital can be done through formal and non-formal education programs and learning by doing (learning by doing). In formal schools, students are required to complete practical assignments, fieldwork, and laboratories. With the ideas and ideas that are constantly from the individual during the education period, such learning methods will become more effective because creativity is embedded. New ideas encourage inspiration that can be comprehended in innovative and productive activities both in the production process and product output. Furthermore, new products act a role in generating maintainable of learning [10]. The levels of learning are divided into 3 categories namely from 'primary level', 'secondary stage' and higher education so that human capital is also differentiated based on the achievement of graduation levels. The impact of human investment progress on economic growth has different patterns and forms between countries in different income levels, geographical and demographic. Its government policy towards education also distinguishes the pattern of the impact of human capital on growth in each country. In principle, human capital level in each country is important to play a role in various fields / sectors. Therefore, investment allocation in education must be separated into primary, secondary and tertiary levels. Investment priority is based on how far human capital at its level has an impact on economic growth [11]. Human capital at the level that gives the greatest impact on economic growth will receive the highest investment priority, and vice versa.

The most basic human needs are clean water for a variety of individual domestic uses, and sanitation and environmental ecosystems. Because water is the object most needed by humans, the availability of water must be able to meet the needs of society as a whole [6]. The standard requirement for clean individual water to drink is 5 liters a day. The need for individual clean water for health and sanitation is 20 liters per day. So it is suggested that the most basic human needs to be met is 25 liters per day per person. So that basic requirements with an extra 15 litre per person per day for bathing and 10 litre per individual per day for cookery. Thus, the requirement for clean water per person per day is projected at the 50 liters [5].

Besides, the clean water needed by human beings individually for their daily life. Commercially, large quantities of water are also needed for the agricultural sector to produce agricultural commodities for food, and others. Clean water is also needed for the non-agricultural sector, especially the industrial sector as an input to produce certain goods and services. [5]. This unique and needed water characteristic results in new views and ideas. New principles and approaches to clean water are developing in this modern era [12]. The use of non-structural substitutions to meet concerns must obtain higher urgency. So, economic principles must be applied more frequently and reliably to water use and management. Clean water supply systems must be efficient, flexible and powerful. Involving parties in the community such as endogenous organizations needs to be suggested because the presence of water has links to social, economic and environmental aspects. Development of management systems must be developed continuously. If related to community interests, the presence of water becomes very strategic and important for all parties [9].

The integrated urban water cycle system contributed to the improvement of human health and hygiene. The integrated system improved the water quality of the influents for drinking water by allocating the dam waters with high water quality primarily to the water demand systems using drinking water and allocating the river waters with low water quality primarily to the water demand systems using industrial water. Restructuring the clean water network system makes the potential of dropping average concentrations of pollutants in the influents provided for drinking water usage, thereby cultivating human health and hygiene and of dropping overall volume of water resources and electricity feeding by the infrastructure and public services [13]. The designs of the dam and the water distribution system have improved water quality and compliance with water customers appropriately. Clean water management technology has also made a major contribution to overcoming the problem of water in the community.

Accumulation of human capital and physical capital through savings, through secondary level of education and social wealth through civil liberties is inversely related to the share of ordinary wealth in national prosperity. Economic development is contrarywise related to natural source necessity as well as to initial income and directly related to the grade of education, investment and civil liberties. Even if the dependence on natural resources unfavorably influences investment, education, civil liberties and growth, the abundance of natural resources measured by resources per head of population varies directly with investment, education, civil liberties and growing [14].

So high economic growth does not absolutely depend on the wealth of natural resources owned by a country, precisely what determines growth is the quality of human resources as an active production factor. Therefore, in this study we will estimate economic growth through the level of participation in pure education and access to clean water by households in 500 districts and cities in Indonesia. 


\section{Methodology}

This study usages data that contains cross sections in 500 cities \& municipality and in the year of 2016 from the country wide. The purpose of this study is to clarify the scope to which economic growth is prejudiced by the presence of clean water, and enrolment of schooling, so that the dependent variable is the growth of GDRP. The basic agenda for investigating data is a regression model of the formula:

$$
L n_{-} G D R P_{i}=\alpha_{0}+\alpha_{1} \text { Enrol_J }+\alpha_{2} H H_{-} W+\varepsilon_{i}
$$

The usage of GDRP without oil is projected that the economic events of individuals in all regions of all of Indonesia are more replicated in GDRP without oil compared to petroleum mining. GDRP variables are created in natural $\log$ form to express the natural growth of GDRP without oil and gas. The education participation indicator in Indonesia is used for the duration of gaining education at the secondary school level, because the grade of production technology in agriculture and industry in Indonesia is sufficient to be done by workers at the junior secondary school level.

The clarification: Ln_GDRP_N: Log natural GDRP without oil

Enroll_J : The net enrollment rate of the junior high school

HH_W : Household which has water access

Based on the econometric model (multiple regression model), GDP growth can be estimated using the ordinary least square (OLS) method.

\section{Result and Discussion}

In the discussion stage will obtain the extent of registration of schooling in junior school, Household water access, and towards economic growing in 500 cities and municipalities during the year 2016. The partial and joint analysis in this model is as follows: The effect hypothesis of enrolment of schooling in junior school level on Economic Development is explained as follows:

The effect hypothesis of enrolment of schooling in junior school level on economic growth is explained as follows:

$\mathrm{H}_{0}$ : enrolment of schooling in junior school level does not affect economic growth

$\mathrm{H}_{1}$ : enrolment of schooling in junior school level affect economic growth

The effect hypothesis of household water access on economic growth is explained as follows:

$\mathrm{H}_{0}$ : the household water access does not affect economic growth

$\mathrm{H}_{1}$ : the household water access affects economic growth

Data analysis was performed by following the Ordinary Least Square econometric model framework [15]. From the collected data for this study were processed by application software STATA Release 15.

Table 1. Result of Regression Analysis

\begin{tabular}{|c|c|c|c|c|}
\hline \multicolumn{5}{|c|}{ ORDINARY LEAST SQUARED MODEL } \\
\hline \multirow{5}{*}{\multicolumn{2}{|c|}{ Ln_GDRP_N }} & \multicolumn{3}{|c|}{ Number of obsercation $=500$} \\
\hline & & \multicolumn{2}{|l|}{$\mathrm{F}(2,497)$} & $=61.32$ \\
\hline & & \multicolumn{2}{|l|}{ Prob. $>\mathrm{F}$} & $=0.0000$ \\
\hline & & \multicolumn{2}{|l|}{ R-squared } & $=0.1979$ \\
\hline & & \multicolumn{2}{|c|}{ Adj R-squared } & $=0.1947$ \\
\hline Variables & Coefficient & Std. Err. & t-test & $P>|t|$ \\
\hline Enrol_J & 0.0162948 & 0.0050567 & 3.22 & 0.001 \\
\hline HH_W & 0.0266446 & 0.0029707 & 8.97 & 0.000 \\
\hline Constant & 12.05065 & 0.3213777 & 37.5 & 0.000 \\
\hline
\end{tabular}

Source: data processing 
In summary the results of the regression analysis are as follows:

$$
L n_{-} G D R P_{i}=12.05065+0.0162948 \text { Enrol }_{J}+0.0266446 H_{-} H_{W}
$$

Tabel 1 displays the results of the analysis of the F test of 61.32 and probability> F of 0.0000 shows that all the independent variables of participation in junior high school education and household access to clean water together influence the independent variables of economic growth significantly.

The results of the regression calculation, the variable of Enrol_J, is significantly affects on economic growth. It means that every year increase in enrolment of schooling in junior school level will increase $0.016 \%$ economic growth of the nation. From the results of this regression, the HH_W variable significantly affects economic growth. Every percentage increase in the household water access will increase $0.027 \%$ economic growth.

\section{Conclusion}

The figure of the coefficient of the variable HH_W is greater than the Enrol_J variable, it is indicating that the level of household access needs for the clean water is more important than education. Therefore, the application of the management of the distribution of water sources (intake) to the community effectively. The volume of water sources and scattered community locations requires a water strategic management that is always dynamic condition from time to time needs and guarantees availability from the operators. However, it cannot be denied that the importance of education participation in promoting sustainable growth to achieve the performance of the Indonesian state.

Herewith, through this research, the suggestions and recommendation for central government as well local government to avail and to develop enrolment of schooling and the new clean water especially the remote areas over the country. The sustainable and good management of those variables become the benefit of the people of this country that will improve the competitiveness of the national economy growth over other countries and will contribute the equitable development.

\section{Acknowledgement}

We are grateful to the Center of Research and Community Development, Office of Research and Publication Faculty of Economics and Business, Universitas Pelita Harapan (UPH). They supported and financed all research activities up to its reporting.

\section{References}

[1] P. M. Romer, "The Origins of Endogenous Growth," J. Econ. Perspect., vol. 8, no. 1, pp. 3-22, 1994.

[2] R. Atalay, "The Education and the Human Capital to Get Rid of the Middle-income Trap and to Provide the Economic Development," Procedia - Soc. Behav. Sci., vol. 174, pp. 969-976, 2015.

[3] S. Budiono, "Pengaruh Investasi Modal Fisik Dan Modal Manusia Serta Beberapa Variabel Demografi Terhadap Pertumbuhan Ekonomi Indonesia Selama 1987 - 1995,” Universitas Indonesia, 2001.

[4] T. Gylfason and G. Zoega, "Education, Social Equality and Economic Growth : A View of the Landscape," vol. 49, pp. 557-579, 2003.

[5] J. Chenoweth, "Minimum water requirement for social and economic development," Desalination, vol. 229, no. 1-3, pp. 245-256, 2008.

[6] G. P. H, "The Human Right to Water," Water Policy, vol. 1, no. 1998, pp. 487-503, 1998.

[7] D. Grey and C. W. Sadoff, "Sink or Swim? Water security for growth and development," Water Policy, vol. 9, no. 6, pp. 545-571, 2007.

[8] S. Budiono, "Teknologi, Perdagangan Internasional Dan Pertumbuhan Ekonomi: Suatu Kajian Teori Ekonomi Klasik ke Perdagangan Internasional Modern,” J. Ris. Manaj. dan Bisnis, vol. 6, pp. 69-93, 2011.

[9] J. T. Purba, "Strategic Innovation Through Technology Readiness and Acceptance in Implementing ICT for Corporate Sustainability," in the 12th International Annual Symposium on Management, 2015.

[10] N. G. Mankiw, D. Romer, and D. N. Weil, "A Contribution to the Empirics of Economic Growth," Q.J. Econ., vol. 107, no. 2, pp. 407-437, 1992.

[11] N. Gemmell, "Evaluating the Impact of Human Capital Stocks and Accumulation on Economic Growth: Some New Evidence," vol. 1, pp. 9-28, 1996.

[12] P. Pleik, "The changing water paradigm: a look at twenty-first century water resource development," Water Int., vol. 25, no. 1, pp. 127-138, 2000.

[13] S. Lim, S. Suh, J. Kim, and H. Suck, "Urban water infrastructure optimization to reduce environmental 
impacts and costs," J. Environ. Manage., vol. 91, no. 3, pp. 630-637, 2010.

[14] T. Gylfason and G. Zoega, "Natural Resources and Economic Growth : The Role of Investment," 2006.

[15] W. H. Greene, Econometric Analysis: Library of Congress Cataloging-in-Publication Data. 2007. 